\title{
Ateizm i dyskryminacja w obliczu współczesnych zmian na świecie
}

\section{KEYWORDS}

atheism, New Atheism, discrimination, humanism

\begin{abstract}
Łopuszańska Urszula, Zacharska Adrianna, Gierszon Patrycja, Samardakiewicz Marzena, Ateizm i dyskryminacja w obliczu współczesnych zmian na świecie [Atheism and discrimination in the face of contemporary changes in the world]. Kultura - Społeczeństwo - Edukacja nr 1(17) 2020, Poznań 2020, pp. 279-287, Adam Mickiewicz University Press. ISSN 2300-0422. DOI 10.14746/kse.2020.17.12.1
\end{abstract}

The aim of this article is to present the situation of atheists around the world in the face of political and cultural changes in the world due to the increase in religious radicalism, particularly Islamic one, migration and terrorism. The article is of an illustrative character and presents the review of English literature in the scope of the discussed subject matter. Furthermore, the results of the latest global reports on prevalence of atheism in the world and the phenomenon of discrimination against persons not identifying with any faith: atheists, humanists or freethinkers were presented. The results of the selected, recent studies on the social perception of atheists and the phenomena of discrimination against them were shown. Another raised issue was the new social movement called New Atheism widespread mainly in the countries of the Western culture that in the future can constitute a new social and political challenge.

* ORCID https://orcid.org/0000-0001-6517-7577.

** ORCID https://orcid.org/0000-0002-2969-3280.

*** ORCID https://orcid.org/0000-0002-2793-0756. 


\begin{abstract}
Conclusions: Between 2005 and 2012 the number of atheists increased by $3 \%$ and currently they constitute $13 \%$ of the population of the world, while the percentage of religious people decreased by $9 \%$. Atheists like other minority groups are discriminated against and their situation is dependent on the country in which they live. However, the vast majority of countries in the world violates the rights of persons identifying themselves as atheists. Still, in some countries, the declaration of atheism is forbidden, and in 13 countries the death penalty can be imposed.
\end{abstract}

\title{
Wstęp
}

Początek XXI wieku przyniósł nowe wyzwania dla rządów krajów na całym świecie polegające przede wszystkim na zapewnieniu bezpieczeństwa obywatelom (Guild, 2009: 1-19). Współcześnie terroryzm stał się poważnym zagrożeniem, a z jego śmiertelnym obliczem spotkało się wiele krajów i nacji na świecie. Według statystyk najwięcej osób ginie z rąk zamachowców w Iraku, Afganistanie, Nigerii, Pakistanie (Global Terrorism Index, 2016). Pomimo postępu technologicznego, który wiąże się raczej z sekularyzacją społeczeństw, sprawy wiary i religii podzieliły wiele grup społecznych (Moberg, Partridge, 2017: 11-54). Religia stała się narzędziem do wywierania wpływu na ludzi oraz swoistą osłoną w sprawach politycznych. Pod pretekstem szerzenia aspektów wiary wybuchają nowe wojny i konflikty zbrojne, czego najlepszym przykładem są rządy samozwańczego Państwa Islamskiego ISIS (Shamieh, Zoltan, 2015: 363-378).

Ostatnio wiele uwagi poświęca się pojęciu islamizacji, czyli radykalizmowi religijnemu, w ramach którego dąży się do powstania państwa żyjącego zgodnie z prawami szarijatu (Machnikowski, 2016: 305). Pod tym pretekstem łamane są prawa człowieka i mniejszości, w tym również prawa do wyznawania własnych poglądów religijnych i politycznych (Monshipouri i in., 2017: 1). Ma to miejsce głównie na Bliskim Wschodzie, ale problem radykalizmu religijnego i terroryzmu dotyka coraz więcej krajów na świecie (Li i in., 2016: 175), w tym także krajów z kręgu kultury zachodniej. Dowodem tego są liczne zamachy terrorystyczne w Europie. W 2015 roku we Francji tylko w jednym zamachu terrorystycznym zginęło 148 osób, a 350 zostało rannych. Jak powszechnie wiadomo, co jakiś czas ataki te przybierają na sile i pochłaniają coraz więcej ofiar (European Union Terrorism Situation and Trend Report, 2017).

Działania pod pretekstem ruchu religijnego, dążące do zagarnięcia nowych obszarów, przyczyniły się do migracji ludności zamieszkujących tereny objęte 
konfliktem zbrojnym i społecznym głównie do Europy Zachodniej (Wirth, 2016: 45). Spowodowało to wzrost niepokojów społecznych w EU, czego dowodem są rządy populistów, partii politycznych o charakterze nacjonalistycznym w niektórych krajach (Monshipouri i in., 2017: 1).

Czy w obliczu takich wydarzeń na świecie wzrasta liczba osób religijnych, czy osób nieutożsamiających się z żadną wiarą? Czy ateiści mogą w przyszłości pomóc w mediacji między stronami konfliktów religijnych i kulturowych? Czy ateiści ze względu na nieangażowanie się w sprawy religijne są dyskryminowani? Odpowiedzi na te pytania będą szukać autorzy niniejszej pracy.

\section{Podstawowe pojęcia}

Aby móc odpowiedzieć na pytania postawione we wstępie, należy wyjaśnić podstawowe pojęcia z obszaru religii i ateizmu. Istnieje kilka definicji ateizmu proponowanych przez osoby duchowne i świeckie. Najprostszą z nich jest przekonanie, że nie istnieje żaden Bóg ani bogowie. W opozycji do ateistów są teiści, którzy wierzą w istnienie Boga lub bogów (Cliteur, 2009). W Oxford Dictionary znajdziemy wyjaśnienie pojęcia agnostyk - „to osoba, która wierzy, że nie ma żadnej pewności co do istnienia Boga" (Oxford Dictionary a, 2017). W opozycji do agnostyków są gnostycy, którzy są przekonani o istnieniu Boga (Oxford Dictionary b, 2017).

Kolejnym pojęciem często używanym w publikacjach anglojęzycznych jest niereligijność (ang. non-religion), (Nixon, 2020: 1). Przeważnie termin ten kojarzony jest $z$ brakiem czegoś metafizycznego (religii). Według Lee (Lee, 2015: 32), termin „non-religion” powinien być używany w odniesieniu do "pojawienia się czegoś nowego". Można powiedzieć jednak, że non-religion jest szerszą kategorią, w której skład wchodzą pojęcia takie jak: naturalizm (nauka, wiedza), humanizm (wartości ludzkie, prawa ogólnoludzkie, wolność), wolnomyślicielstwo, sceptycyzm, ateizm (Hemming, 2017: 113-129; WIN-Gallup International, 2012).

\section{Religijność i ateizm na świecie}

W świetle The Global Index of Religiosity and Atheism (WIN-Gallup International, 2012) w 2012 roku na świecie 59\% osób określiło samych siebie jako osoby religijne, $23 \%$ jako osoby niereligijne, a 13\% osób przyznało, że są ateistami. Ateiści skoncentrowani są głównie w Azji i Europie; na liście dziesięciu najbardziej ateistycznych państw znalazły się: Chiny, Japonia, Czechy, Francja, Korea Południowa, Niemcy, Holandia, 
Australia, Irlandia. Należy zwrócić uwagę, że powyższe badanie dotyczyło własnej percepcji, być może deklaracja uczestników nie zawsze odzwierciedla faktyczny stan. W kolejnym zestawieniu przedstawiono dziesięć państw, w których obywatele określili siebie jako osoby religijne. W tym przypadku państwa te są rozproszone w świecie. Należą do nich: Ghana, Nigeria, Armenia, Fidżi, Macedonia, Rumunia, Irak, Kenia, Peru, Brazylia. Należy podkreślić, że między 2005 a 2012 rokiem odnotowano pewne zmiany, które wskazują, że religijność obniżyła się o 9\%, podczas gdy liczba ateistów wzrosła o 3\%. Dodatkowo, wskaźnik występowania ateizmu jest wyższy wśród osób z wyższym wykształceniem, podczas gdy religijności wśród osób z niższymi dochodami (WIN-Gallup International, 2012).

\section{Czy ateiści są dyskryminowani?}

Najprostsza definicja dyskryminacji mówi, że mamy z nią do czynienia, gdy jedna osoba traktuje drugą niesprawiedliwie, ponieważ ta druga jest członkiem innej grupy. Zachowania te mogą być okazywane względem osób indywidualnych oraz grup, na przykład etnicznych, w sposób jawny, bezpośredni lub ukryty (Whitley, Kite, 2009: 19).

W badaniu wykazano, że wysokie nasilenie depresji, niższe kompetencje grupowe (ang. lower intergroup competence) wiążą się z częstszym doświadczaniem dyskryminacji ze strony innych (Phinney i in., 1998: 927). Osoby z niższym poczuciem własnej wartości są częściej dyskryminowane, co w rezultacie prowadzi do jeszcze głębszych problemów natury psychologicznej (Major i in., 2003: 147).

Skutki dyskryminacji grup mniejszościowych są przeważnie takie same: gorsze warunki nauki, trudność w uzyskaniu pracy, szczególnie na stanowiskach społecznych, trudniejszy dostęp do leczenia, niesprawiedliwość społeczna i sądowa (Bond i in., 2010: 3).

Wydawać by się mogło, że ateiści jako osoby niezaangażowane w sprawy religijne, wyznające prawa ogólnoludzkie, w tym moralne, mogą budzić neutralne odczucia ze strony osób religijnych. W świetle artykułu 18 Powszechnej deklaracji praw człowieka każdy ma prawo do wyrażania własnych myśli i poglądów, a także do ich zmiany, w tym również do zmiany poglądów religijnych. Prawo to obowiązuje od 1948 roku (Universal Declaration of Human Rights, 1948). Czy jest przestrzegane na świecie? Jaki jest rzeczywisty obraz sytuacji ateistów?

Według A Global Report on Discrimination Against Humanists, Atheists, and the Non-religious z 2015 roku ateiści na całym świecie doświadczają dyskryminacji nawet w krajach wysoko rozwiniętych (A Global Report on Discrimination..., 2017). 
W raporcie tym ze względu na przestrzeganie praw ateistów, humanistów i wolnomyślicieli państwa zostały podzielone na pięć kategorii: (1) wolna i równa, (2) zadowalająca, (3) systemowa dyskryminacja, (4) poważna dyskryminacja, (5) poważne naruszenia. W świetle tego raportu sytuacja oceniona jako wolna i równa wystąpiła jedynie w Belgii, Holandii, Estonii, Kosowie, na Tajwanie, Nauru, Fiji, Kiribati. Natomiast poważne naruszenia wystąpiły w Gambii, Mauretanii, Nigerii, Suazi, Komorach, Sudanie, Libii, Egipcie, Erytrei, Somalii, Etiopii, Jordanii, Arabii Saudyjskiej, Jemenie, Zjednoczonych Emiratach Arabskich, Katarze, Bahrajnie, Kuwejcie, Iraku, Syrii, Republice Arabskiej, Iranie, Afganistanie, Pakistanie, Bangladeszu, Malediwach, Chinach, Malezji, Indonezji, Brunei i Korei Północnej. W pozostałych krajach stwierdzono systemową dyskryminację lub poważną dyskryminację. W 55 krajach bluźnierstwo lub naruszenie uczuć religijnych uważa się za przestępstwo zapisane w kodeksie prawnym. W 39 z nich za wyżej wymieniony czyn grozi kara pozbawienia wolności. W krajach EU, takich jak Dania, Niemcy, Grecja, Węgry, Malta i Polska, za bluźnierstwo grozi kara pozbawienia wolności do lat trzech. Należy podkreślić, że w niektórych krajach identyfikowanie siebie jako ateisty jest w dalszym ciągu nielegalne. W 19 krajach na świecie przewidziana jest za to kara, w $13 \mathrm{z}$ nich karą za to jest śmierć (A Global Report on Discrimination..., 2017).

\section{Jaki jest spoleczny obraz i odbiór ateistów?}

Zdecydowana większość badań w tym zakresie pochodzi ze Stanów Zjednoczonych. W tym kraju w 2008 roku przeprowadzono badanie identyfikacji religijnej, American Religious Identification Survey (ARIS), na którym opiera się spora część badań. W świetle tego raportu $24 \%$ osób identyfikujących się jako niereligijne, formalnie byli katolikami. Etnicznie było to przede wszystkim Azjaci, Irlandczycy i Żydzi. 60\% stanowili mężczyźni, podczas gdy kobiety stanowiły 40\% (Kosmin in., 2008: 1). $41 \%$ ateistów przyznało, że w przeciągu pięciu ostatnich lat z powodu braku identyfikacji religijnej doświadczyło dyskryminacji, takiej jak: oszczerstwo, przymus, społeczny ostracyzm, odmowa możliwości kupienia towarów i usług oraz nienawiść (Hammer in., 2012: 43).

Co ciekawe, najsilniejszym predykatorem dyskryminacji nie był teologiczny ateizm ani agnostycyzm, ale samo identyfikowanie siebie jako ateisty lub agnostyka (dotyczyło to sytuacji, gdy osoby pytano o ich identyfikację religijną). Pozostałymi predykatami były: wiek, region kraju, tereny wiejskie versus miejskie, rodzinne oczekiwania religijne, pochodzenie etniczne i rasa. Osoby przejawiające 
bardziej zdecydowane poglądy w większym stopniu doświadczyły dyskryminacji (Cragun i in., 2012: 105).

Międzykulturowy eksperyment przeprowadzony w Wielkiej Brytanii, Chinach i Malezji (w grupie ponad 600 osób) z wykorzystaniem 88 rund binarnej wersji gry zaufania (ang. binary version of the trust game) wykazał, że zarówno osoby religijne, jak i ateiści uważali, że osoby religijne są bardziej godne zaufania. Osoby religijne ponadto wykazywały tendencję do okazywania większego zaufania wobec osób należących do tej samej wiary. Religijność wiązała się również ze skłonnością do dyskryminacji osób niereligijnych (Chuah i in., 2016: 280).

W kolejnym eksperymencie przeprowadzonym w grupie 618 osób posłużono się stworzoną przez autorów postacią Jordana, młodego mężczyzny z ostatniego roku architektury. Uczestnicy zostali podzieleni na cztery grupy, każda otrzymała ten sam opis dotyczący Jordana, ale $z$ inną podstawową informacją mówiącą, że Jordan był: (1) ateistą, (2) bez wiary w Boga, (3) religijny, (4) nieżonaty. Potem poproszono ich o ewaluację tej osoby. Jordan otrzymał więcej ocen negatywnych, kiedy został zidentyfikowany jako ateista niż gdy jego religijność nie była wspomniana lub gdy zidentyfikowano go jako osobę religijną. Nie odnotowano statystycznie istotnych różnic między opisami ateista a wyrażeniem: bez wiary w Boga. Co spowodowało, że uczestnicy ocenili negatywnie stworzonego na potrzeby badania chłopca, który otrzymał etykietę ateista? Według autorów ludzie reagują negatywnie na stwierdzenie „ateista”, ponieważ wywołuje to u nich specyficzną reakcję na brak wiary w Boga. Można zatem wysunąć wniosek, że aspekty wiary są ważniejsze w odbiorze społecznym człowieka niż jego czyny i wartości, które wyznaje (Lawton, Heesacker, 2012: 32).

\section{Nowy ateizm \\ jako wyzwanie dla polityków i społeczeństw}

Nowy ateizm (ang. new atheism), znany również jako „ateizm wojowniczy” (ang. militant atheism), jest nowym antyreligijnym ruchem. W jego powstaniu znaczącą rolę odegrała książka Bóg urojony (ang. The God Delusion) autorstwa Richarda Dawkinsa, która w 2006 roku znalazła się na liście bestselerów (Mcanulla, 2012: 91). W książce tej autor przedstawia fakty, dowody na nieistnienie Boga, odwołuje się również do teorii ewolucji. Formułuje postulat, że ateiści mogą by szczęśliwi i spełnieni intelektualnie, a także moralni. Bycie ateistą dowodzi zdrowego i nie- 
zależnego umysłu. Wyraża pogląd, że dzieci są oceniane przez pryzmat wiary ich rodziców, co wedługg niego nie powinno mieć miejsca (Dawkins, 2016).

Jakie są cechy wspólne nowych ateistów? Przeważnie nie afiliują się z żadną partią polityczną. Jeśli już, to wspierają wartości i kampanie liberalne. W porównaniu do osób religijnych, współcześni ateiści to przeważnie młodzi mężczyźni, z wyższym poziomem wykształcenia, osiągający wyższe dochody. Przede wszystkim są nonkonformistami, wykazują większą tolerancję. Okazują się również mniej autorytarni i mniej dogmatyczni niż ludzie wierzący (Kettel, 2013: 62).

W obliczu ich rosnącej siły można spodziewać się, że będą stanowili (szczególnie w niektórych krajach) sporą grupę osób niechętnie uczestniczących w życiu politycznym. Określenie „wojowniczy” wywołuje jednak wrażenie, że nowi ateiści będą domagać się swoich praw mniejszościowych. Pozostaje tylko pytanie, czy reszta społeczeństwa będzie na to gotowa.

\section{Podsumowanie}

Ateiści i osoby niereligijne to osoby wyznające prawa ogólnoludzkie; często postulują humanistyczne wartości w życiu. Wśród osób religijnych w większości wzbudzają negatywne odczucia, czego dowodzą eksperymenty naukowe w tym zakresie. Największą trudnością jest dla osób religijnych wyobrażenie sobie, że ktoś nie wierzy w Boga. Wydaje się, że u niektórych osób wierzących wywołuje to lęk.

Ateiści i „non-religions”, podobnie jak i inne grupy mniejszościowe, są dyskryminowani na świecie, nawet w krajach z kręgu kultury zachodniej. Skutkuje to problemami społecznymi, spowodowanymi chociażby brakiem dostępu do świeckich szkół, jak również psychologicznymi. Dyskryminacja może przyczyniać się do obniżenia poczucia własnej wartości, nasilenia objawów depresyjnych.

Obraza uczuć religijnych może wiązać się z karą pozbawienia wolności, w najgorszym przypadku ateistom odbiera się nawet prawo do egzystencji. Ich sytuacja różni się w zależności od państwa, w którym żyją, niemniej jednak najtrudniejsza jest na Bliskim Wschodzie. W XXI wieku w dalszym ciągu nielegalne jest identyfikowanie siebie jako ateisty. W 13 krajach karą za to może być śmierć.

W obliczu radykalizacji podglądów na świecie, wywołanych chociażby terroryzmem, zauważalny jest wzrost liczby ateistów. Wydaje się, że ruch ateizmu rośnie w siłę, przybierając charakter wojowniczy, o czym świadczy ruch nowego ateizmu. 


\section{Bibliografia}

A Global Report on Discrimination Against Humanists, Atheists, and the Non-religious, (IHEU), (2015), http://iheu.org/newsite/wp-content/uploads/2015/12/FOT15-FULL-v0_2.pdf, dostęp: 29.05.2017.

Assembly U.G. (1948), Universal Declaration of Human Rights, UN General Assembly.

Bond L., McGinnity F., Russell H. (2010), Introduction: making equality count, [w:] L. Bond, F. McGinnity, H. Russell (red.), Making Equality Count: Irish and International Research Measuring Equality and Discrimination, Dublin, s. 1-19.

Chuah S.H., Gächter S., Hoffmann R., Tan J.H. (2016), Religion, discrimination and trust across three cultures, European Economic Review, 90, s. 280-301.

Cliteur, P. (2009), The Definition of Atheism, https://dspace2.creighton.edu/xmlui/handle/10504/64446, dostęp: 31.05.2017.

Cragun R.T., Kosmin B., Keysar A., Hammer J.H., Nielsen M. (2012), On the receiving end: Discrimination toward the non-religious in the United States, Journal of Contemporary Religion, 27(1), s. $105-127$.

Dawkins R. (2016), The God Delusion, London.

European Union Terrorism Situation and Trend Report 2016, https:/europol.europa.eu, dostęp: 31.05.2017.

Global Terrorism Index 2016, (2016), Institute for Economics \& Peace, s. 94-95, http://economicsandpeace.org, dostęp: 31.05.2017.

Guild E., (2009), Security and Migration in the $21^{\text {st }}$ Century, Cambridge.

Hammer J., Cragun R., Hwang K., Smith J. (2012), Forms, frequency, and correlates of perceived anti-atheist discrimination, Secularism and Nonreligion, s. 43-67.

Hemming P.J. (2017), Childhood, youth and non-religion: Towards a social research agenda, Social Compass, 64(1), s. 113-129.

Kettell S. (2013), Faithless: The politics of new atheism, Secularism and Nonreligion, 2, s. 61-67.

Kosmin B.A., Keysar A., Cragun R., Navarro-Rivera J. (2009), American Nones: The profile of the no religion population, a report based on the American religious identification survey 2008, Hartford.

Lawton S., Heesacker M. (2012), Anti-atheist bias in the United States: Testing two critical assumptions, Secularism and Nonreligion, 1, s. 32-42.

Lee L. (2015), Recognizing the Non-Religious: Reimagining the Secular, Oxford.

Li Z., Sun D., ChenH., Huang S.Y. (2016), Identifying the socio-spatial dynamics of terrorist attacks in the Middle East, In Intelligence and Security Informatics (ISI), 2016 IEEE Conference, s. 175-180.

Machnikowski R.M. (2016), Terroryzm jako globalne zagrożenie XXI w., [w:] T. Domański (red.), Międzynarodowe studia polityczne i kulturowe wobec wyzwań współczesności, Łódź, s. 295-307.

Major B., Quinton W.J., Schmader T. (2003), Attributions to discrimination and self-esteem: Impact of group identification and situational ambiguity, Journal of Experimental Social Psychology, 39(3), s. 220-231.

Mcanulla S. (2012), Radical atheism and religious power. New atheist politics, Approaching Religion, 2(1), s. 87-99.

Moberg M., Partridge C. (2017), The study of religion and popular music: theoretical perspectives, methodologies and issues, [w:] C. Partridge, M. Moberg (red.), The Bloomsbury Handbook of Religion and Popular Music, Bloomsbury, s. 11-54. 
Monshipouri M., Welch Jr C.E., Nikazmrad K. (2017), Protecting human rights in the era of uncertainty: How not to lose the war against ISIS, Journal of Human Rights, 16(1), s. 1-24.

Nixon A.G. (2020), 'Non-religion' as part of the 'religion' category in international human rights, Religions, 11(79), s. 1-18.

Oxford Dictionary a, (2017), https://en.oxforddictionaries.com/definition/agnostic, dostęp: 29.05.2017.

Oxford Dictionary b, (2017), https://en.oxforddictionaries.com/definition/gnosticism, dostęp: 29.05.2017.

Phinney J.S., Madden T., Santos L.J. (1998), Psychological variables as predictors of perceived ethnic discrimination among minority and immigrant adolescents, Journal of Applied Social Psycho$\log y, 28(11)$, s. 937-953.

Shamieh L., Zoltan S. (2015), The Rise of Islamic State of Iraq and Syria (ISIS), Defense Against Terrorism Review, 14(4), s. 363-378.

Whitley B., Kite, M. (2009), The Psychology of Prejudice and Discrimination, Princeton.

WIN-Gallup International (2012), Global index of religiosity and atheism, http://www.wingia.com/ web/files/news/14/file/14.pdf Google Scholar, dostęp: 5.05.2017.

Wirth T. (2016), The European Union's framing of the European refugee crisis, Elon Journal, s. 45-56. 
